\title{
PENGARUH STRATEGI PENGORGANISASIAN ELABORASI DAN GAYA KOGNITIF SPASIAL MAHASISWA TERHADAP HASIL BELAJAR GAMBAR MESIN
}

\author{
Aan Ardian ${ }^{1}$, Zainur Rofiq ${ }^{2}$ \\ ${ }^{1,2}$ Jurusan Pendidikan Teknik Mesin, Fakultas Teknik, UNY \\ aan_ardian@uny.ac.id
}

\begin{abstract}
The purpose of this study are: (1) to determine the effect of elaboration organization strategy and textbook for students with distinct spatial cognitive style on learning outcomes of Mechanical Drawing course, (2) interaction between the learning strategy and the cognitive style in effect to the learning outcomes of Mechanical Drawing course. The methods being used was quasi experiment with 2 by 2 factorial design and Pretest-Posttest Control Group Design. Research population was all student enrolled in the Mechanical Drawing course. Results show that elaboration learning strategy perform better in the learning outcomes of mechanical drawing compared to using textbook, for students with high spatial cognitive. It also confirmed that there is an interaction between learning strategy and spatial cognitive which affects mechanical drawing skills of the students.
\end{abstract}

Keywords: elaboration organization strategy, spatial cognitive, engineering drawing, learning outcome

\begin{abstract}
ABSTRAK
Tujuan penelitian ini adalah: (1) mengetahui pengaruh strategi pengorganisasian elaborasi dan buku teks pada mahasiswa yang memiliki gaya kognitif spasial berbeda terhadap hasil belajar mata kuliah Gambar Mesin, (2) interaksi antara strategi pembelajaran dengan gaya kognitif dalam pengaruhnya terhadap hasil belajar mata kuliah Gambar Mesin. Penelitian ini menggunakan metode quasi experimen yang dilaksanakan dengan rancangan faktorial 2 x 2 dan Prestest-Posttest Control Group Design. Populasi penelitian adalah seluruh mahasiswa Jurusan Pendidikan Teknik Mesin Fakultas Teknik UNY yang mengikuti perkuliahan Gambar Mesin. Hasil penelitian menunjukkan bahwa rerata nilai keterampilan gambar mesin mahasiswa yang diajar dengan strategi pembelajaran Elaborasi sebesar 63,13 dan rerata nilai untuk strategi pembelajaran buku teks sebesar 57,97. Strategi pembelajaran secara elaborasi memberikan hasil keterampilan gambar mesin yang lebih tinggi daripada menggunakan buku teks bagi mahasiswa yang berkemampuan spasial tinggi. Hasil penelitian juga menunjukkan adanya interaksi antara strategi pembelajaran dan kemampuan spasial yang mempengaruhi keterampilan gambar mesin mahasiswa.
\end{abstract}

Kata kunci: strategi pengorganisasian elaborasi, gaya kognitif spasial mahasiswa, hasil belajar gambar mesin

\section{PENDAHULUAN}

Polemik tentang kualitas lulusan Program Diploma 3 tahun (D3), selama ini semakin berkembang sedemikian rupa yang muaranya pada kondisi yang belum memenuhi tuntutan pasar kerja. Hasil survei yang dilakukan oleh Task Force Systems Curriculum ACM (2004: 12) menunjukkan bahwa terjadi jarak antara kompetensi lulusan perguruan tinggi dengan kebutuhan kemampuan tenaga kerja di dunia usaha. Selama ini mahasiswa melakukan kegiatan practicum, content mastery, systemic know mastery, tool and reference needed, dan portofolio, sedangkan dalam dunia usaha atau industri yang dibutuhkan kemampuan tenaga kerja yang melakukan communication skills, team building, systemic thingking, profesionalism, quality, role of enterprise.

Pergeseran paradigma dan apresiasi terhadap ilmu pengetahuan menempatkan sumber daya manusia yang berkualitas (knowledge worker) sebagai aset utama dan kunci penting dalam perusahaan. Pergeseran paradigma ini juga mendorong perubahan besar dalam sikap dan kebiasaan belajar bagi pelaku belajar yang harus secara aktif dengan cara belajar learning how to learn. Peran dosen sebagai faktor utama dan "pemain kunci" dalam proses pembelajaran, sedangkan mahasiswa sangat pasif dan hanya sebagai "penonton" 
masih sering dijumpai dalam proses pembelajaran di perguruan tinggi.

Once Kurniawan (2002: 2) menjelaskan bahwa proses pembelajaran di perguruan tinggi sering dilakukan secara monolog dan menempatkan mahasiswa sebagai obyek dalam pembelajaran, sedangkan dosen sebagai pelaku atau subyek utama, sudah usang dan tidak sesuai dengan perkembangan dan kemajuan ilmu pengetahuan dan teknologi.

Strategi pembelajaran yang selama ini berlangsung perlu dikembangkan sehingga lebih memacu kreativitas dan keaktifan mahasiswa. Sebagai calon tenaga kerja profesional, maka mahasiswa sebaiknya juga dikenalkan dengan cara-cara kerja para profesional yang ada di industri. Selama ini strategi pembelajaran pada mata kuliah Gambar Mesin yang diterapkan adalah strategi pengorganisasian buku teks. Materi pembelajaran menuruti urutan langkah-langkah Gambar Mesin. Setiap langkah menggambar dibahas secara rinci dan sistematis, disertai contoh-contoh dan latihan. Pengalaman menunjukkan bahwa pembahasan secara rinci dan sistematis setiap langkah menggambar sangat banyak menghabiskan waktu dan contoh gambar belum menjangkau masalah gambar keteknikan di lapangan.

Melihat kesenjangan ini, dipandang perlu untuk mengkaji strategi pembelajaran lain yang dapat memberi kemampuan menggambar yang lebih baik dalam waktu yang relatif pendek. Salah satu strategi pembelajaran yang dikaji adalah strategi pengorganisasian elaborasi. Strategi pengorganisasian elaborasi memiliki beberapa pendekatan, yaitu pendekatan mundur, pendekatan memperkecil perbedaan, dan pendekatan memecah tujuan. Selain itu perlu dilihat dari sisi gaya kognitif mahasiswa. Gaya kognitif mahasiswa dalam proses pembelajaran terkait dengan beberapa hal, antara lain: (1) kemampuan dalam menganalisis dan mengorganisasikan informasi yang dirumuskan dalam gaya kognitif spasial rendah dan spasial tinggi; (2) divergensi dan konvergensi arah berpikir yang dirumuskan dalam gaya kognitif divergen dan konvergen, dan (3) spontanitas pemberian respon, yang dirumuskan dalam gaya kognitif reflektif dan impulsif. Kegiatan utama dalam mata kuliah Gambar Mesin adalah mengorganisasi informasi untuk menyusun gambar mesin. Oleh karena itu gaya kognitif, khususnya klasifikasi spasial rendah dan spasial tinggi perlu mendapat perhatian dalam proses pembelajaran Gambar Mesin.

Gambar mesin adalah representasi bidang permukaan suatu obyek atau bagian dari suatu obyek dengan memberikan gambaran bentuk obyek dengan persis dan komplit, dan memberikan semua informasi yang diperlukan untuk keperluan proses manufaktur serta pemeriksaan obyek itu sendiri. Gambar kerja tersebut berisi dimensi dan informasi bahan, pengerjaan permukaan dan informasi teknik lain termasuk spesifikasi untuk keperluan proses produksi dan inspeksi, sehingga insinyur, ilmuwan atau teknisi harus dapat membuat representasi gambar konstruksi suatu peralatan dan mesin, gambar perancangan, dan data yang terkait, maksudnya mereka harus mengerti prinsip-prinsip dasar pembuatan gambar (Giesecke, 1974: 8).

Gupta dan Murthy (1984: 27) berpendapat bahwa kegiatan terakhir dalam proses perancangan adalah membuat deskripsi sempurna susunan konstruksi, elemen, dan sub elemen. Elemen tersebut berupa gambar kerja yang mencakup: bentuk, ukuran dan toleransi, tanda pengerjaan yang disajikan pada tingkat aplikasi, konkrit, dan bermakna, sedangkan rangkuman umumnya menyajikan secara abstrak.

Hal ini menunjukkan bahwa perancang meminta operator untuk mengerjakan suatu benda kerja atau barang dengan memberikan suatu gambar kerja. Dengan kata lain, seorang perencana menuangkan ide-idenya ke dalam gambar, kemudian pelaksana mengerjakan apa yang dikehendaki perencana menurut gambar tersebut. Sehingga dalam peristiwa ini perencana menggunakan gambar sebagai alat komunikasi kepada pelaksana. 
Reigeluth (1983) menyarankan dalam mengorganisasi pembelajaran elaborasi sebaiknya dilakukan dengan memperhatikan langkah-langkah kegiatan sebagai berikut: (1) penyajian epitome, (2) elaborasi tahap pertama, (3) pemberian rangkuman dan sintesis antar gabian, (4) elaborasi tahap kedua, (5) rangkuman dan sintesa akhir. Pijakan teori elaborasi kedua adalah proses ingatan. Teori ingatan menyatakan bahwa informasi verbal yang diterima seseorang disandikan baik dalam bentuk gambaran fisik (episodic) maupun dalam arti makna dan konteksnya (sematic). Selanjutnya informasi tersebut tersimpan sebagai bagian dari bangunan skemata.

Plomp dan Ely (1996) menjelaskan bahwa karakteristik yang perlu diperhatikan dalam merancang buku teks adalah: (1) isi pesan harus dianalisis dan diklasifikasi ke dalam kategori-kategori tertentu, (2) setiap kategori harus di penggal menjadi beberapa penggalan teks, (3) perlu ada penyajian format visualisasi untuk memberikan kemenarikan isi (content appealing), (4) kategori format judul yang berisi bahan harus diseleksi. Strategi pengorganisasian buku teks merupakan penerapan dan pengembangan dari instructional design yang lebih menekankan pada prinsipprinsip yang diadopsi dari teori dan temuan penelitian tentang belajar. Orientasi buku teks adalah untuk mengoptimalkan kegiatan belajar dalam rangka mencapai hasil belajar yang optimal. Oleh karena itu, buku teks harus dapat menyajikan bahan pembelajaran yang bermakna bagi mahasiswa sebagai subyek yang belajar.

Park (1996: 639) membuat definisi yang lebih rinci lagi tentang gaya kognitif yaitu, gaya kognitif merupakan karakteristik individu dalam berpikir, merasakan, mengingat, memecahkan masalah, dan membuat keputusan. Dengan demikian informasi yang tersusun baik, rapi, dan sistematis mungkin lebih mudah diterima oleh individu tertentu sedangkan individu lain lebih mudah menerima informasi yang tersusun tidak terlalu rapi dan tidak terlalu sistematis.
Gaya kognitif memiliki dua kutub yang tidak menunjukkan adanya keunggulan antara satu kutub dengan kutub yang lain. Masingmasing kutub cenderung memiliki nilai positif pada ruang lingkup tertentu, dan cenderung memiliki nilai negatif pada ruang lingkup yang lain. Sebagian besar gaya kognitif yang sudah diselidiki berada pada satu kontinum, dimana sebagian besar individu berada diantara kedua kutub. Hsiao (2000:1) menyatakan bahwa gaya kognitif melibatkan variabel dengan satu dikotomi, seperti global-holistik dengan terfokus-detail, spasial rendah dengan spasial tinggi, atau otak kiri dengan otak kanan.

Witkin (1979:9) menjelasankan individu yang memiliki gaya kognitif spasial tinggi memiliki karakteristik antara lain: (1) memiliki kemampuan berpikir imajinatif yang tinggi, (2) cepat berpikir hal-hal yang abstrak, (3) cepat menerima dan memproses informasi, (4) mempunyai citra mental yang tinggi dalam menganalisis sesuatu, (5) cepat menganalisi obyek yang bersifat visual, (6) cepat memecahkan masalah yang disertai gambar, table, dan grafik, dan (7) dalam mengerjakan tugas tidak tergantung pada orang lain

Individu yang memiliki gaya kognitif spasial tinggi adalah individu yang cenderung memandang obyek terdiri dari bagian-bagian diskrit dan terpisah dari lingkungannya, mampu menganalisis untuk memisahkan stimuli dari konteksnya, mampu untuk merestrukturisasi, berorientasi impersonal, dan bekerja dengan motivasi dan penguatan intrinsik. Dalam penyelesaian tugas, individu spasial tinggi cenderung lebih senang mengerjakan sendiri, lebih mementingkan motivasi dan penguatan intrinsic. Beberapa karakteristik individu yang memiliki gaya kognitif spasial rendah sudah diidentifikasikan oleh Witkin (1979:8) dan kawan-kawannya antara lain: (1) kurang mampu berpikir imajinatif, (2) kurang mampu berpikir masalah-masalah yang abstrak, (3) peran serta citra mental dalam memproses informasi lambat, (4) lambat dalam menganalisis obyek yang bersifat visual, (5) lambat menganalisis obyek yang bersifat visual, 
(6) lambat dalam memecahkan masalah yang disertai gambar, table, dan grafik, (7) dalam mengerjakan tugas memerlukan bimbingan yang rinci, (8) lebih menyukai masalah-masalah yang bersifat verbalisme.

Individu yang memiliki gaya kognitif spasial rendah cenderung baik hati, ramah, dan bijaksana, sehingga lebih mampu untuk menjalin hubungan interpersonal dan lebih mudah diterima orang lain. Akan tetapi kurangnya kemampuan menganalisis, seta kecenderungan untuk menerima informasi seperti disajikan menjadikan individu spasial tinggi menemui kesulitan untuk mengemukakan pendapat dengan persepsi sendiri. Witkin (1979:14) menjelaskan bahwa pengalaman individu spasial rendah terintegrasi dan cenderung lebih holistik, akibatnya individu spasial rendah kurang memiliki keterampilan merestrukturisasi kognitif. Individu spasial rendah cenderung menggunakan pendekatan pasif dalam belajar. Tujuan pembelajaran cenderung diikuti apa adanya, sehingga diperlukan tujuan pembelajaran yang tersusun dengan baik. Struktur materi pembelajaran juga cenderung diikuti sesuai yang disajikan, sehingga diperlukan materi pembelajaran yang terstruktur dengan baik dan sistematis.

Perbedaan karakteristik dari individu spasial tinggi dan sparsial rendah dapat dilihat pada Tabel 1. berikut ini.

Tabel 1 Perbedaan Karakteristik Individu Spasial rendah dan Field Dependent

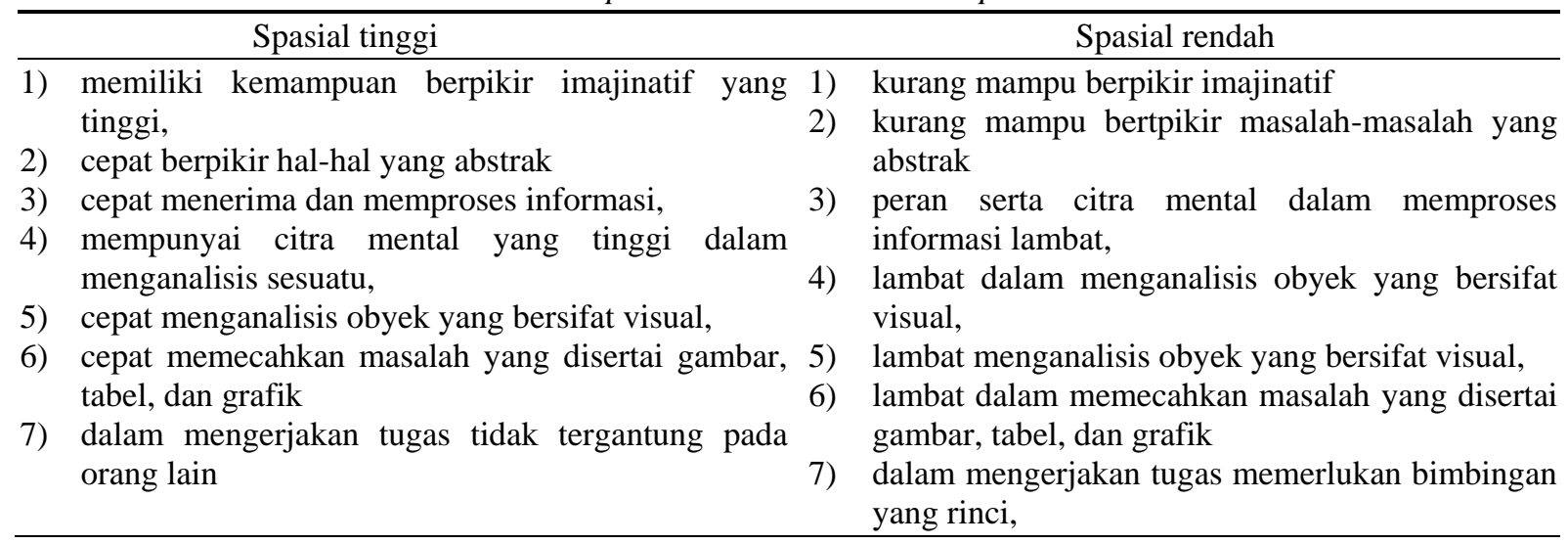

Perbedaan karakteristik individu di atas terdapat keuntungan maupun kerugian bagi mahasiswa dengan kategori gaya kognitif spasial tinggi maupun spasial rendah dan keduanya sangatlah penting dalam proses pembelajaran. Mahasiswa dengan spasial tinggi dalam belajar di kelas dapat diberikan strategi pengorganisasian pembelajaran yang meliputi analisis visual, dan memecahkan masalah yang disertai gambar, tabel, dan grafik, dan penugasan atau latihan-latihan yang dikerjakan secara individual. Berbeda dengan mahasiswa dengan spasial rendah yang lebih membutuhkan penggunaan keterampilan komunikasi interpersonal untuk mendapatkan kemajuan dalam belajar sehingga orientasi terhadap strategi pengorganisasian pembelajaran yang menuntut kerjasama dan bersinergi dalam penyelesaian tugas akan lebih membantu mahasiswa spasial rendah untuk meningkatkan prestasi belajar.

Berdasarkan permasalahan tersebut penelitian dilakukan dengan tujuan untuk mengetahui perbedaan hasil belajar Gambar Mesin antara mahasiswa yang mengikuti perkuliahan dengan strategi pengorganisasian elaborasi dan mahasiswa yang mengikuti perkuliahan dengan strategi pengorganisasian buku teks, perbedaan hasil belajar Gambar Mesin antara mahasiswa yang mengikuti perkuliahan dengan strategi pengorganisasian elaborasi dan mahasiswa yang mengikuti perkuliahan dengan strategi pengorganisasian buku teks bagi mahasiswa yang memiliki gaya 
kognitif spasial tinggi, perbedaan hasil belajar Gambar Mesin antara mahasiswa yang mengikuti perkuliahan dengan strategi pengorganisasian elaborasi dan mahasiswa yang mengikuti perkuliahan dengan strategi pengorganisasian buku teks bagi mahasiswa yang memiliki gaya kognitif spasial rendah, serta interaksi antara strategi pembelajaran dengan gaya kognitif dalam pengaruhnya terhadap hasil belajar Gambar Mesin.

\section{METODE}

Penelitian quasi experimen ini dilaksanakan dengan menggunakan rancangan faktorial $2 \times 2$. Rancangan tersebut termasuk dalam Prestest-Posttest Control Group Design dan diperjelas dengan skema sebagai berikut :

Tabel 2. Skema Rancangan Penelitian.

\begin{tabular}{|c|c|c|}
\hline $\begin{array}{l}\text { Gaya Model } \\
\text { Kognitif } \\
\text { Mahasiswa (b) }\end{array}$ & $\begin{array}{l}\text { Pembelajaran } \\
\text { n Elaborasi } \\
\quad(\mathrm{A} 1)\end{array}$ & $\begin{array}{l}\text { Pembelaja } \\
\text { ran Buku } \\
\text { teks } \\
\text { (A2) }\end{array}$ \\
\hline Spasial Rendah (B1) & $\mathrm{I}$ & II \\
\hline Spasial Tinggi (B2) & III & IV \\
\hline TOTAL & $\mathrm{V}$ & VI \\
\hline
\end{tabular}

Validitas penelitian merupakan usaha untuk menjaga agar hasil uji hipotesis dari penelitian ini sesuai dengan tujuannya. Gangguan yang kemungkinan mempengaruhi hasil penelitian dikendalikan melalui tinjauan validitas internal dan eksternal. Dalam hal ini hasil belajar Gambar Mesin mahasiswa merupakan hasil perlakuan pembelajaran sesuai dengan rancangan penelitian ini. Faktor sejarah yang perlu dikendalikan dalam penelitian ini agar hasil penelitian benar-benar merupakan akibat perlakuan adalah dengan menetapkan waktu perlakuan 1 semester. Faktor waktu tidak ikut mempengaruhi hasil belajar Gambar Mesin. Usaha yang perlu dilakukan yaitu melaksanakan presensi dan pengawasan yang ketat terhadap subyek yang diteliti, serta selalu memberikan motivasi tentang pentingnya mata kuliah Gambar Mesin bagi mahasiswa D3. Validitas ekologi yaitu faktor yang mempengaruhi sejauh mana hasil eksperimen itu dapat digeneralisasikan kepada kondisi lingkungan eksperimen yang lain. Hal ini menunjukkan bahwa dengan adanya pengontrolan terhadap validitas eksternal sebagaimana disebutkan di atas, diharapkan hasil yang diperoleh dalam penelitian ini akan merupakan hasil dari perlakuan yang diberikan.

Populasi dalam penelitian ini adalah seluruh mahasiswa Jurusan Pendidikan Teknik Mesin Fakultas Teknik UNY Yogyakarta yang mengikuti mata kuliah Gambar Mesin. Jumlah populasi sebanyak 240 mahasiswa yang menyebar dalam 6 kelas. Terdapat 4 kelas tempat penelitian, yaitu 2 kelas untuk sampel yang mendapat perlakuan strategi pengorganisasian elaborasi dan 2 kelas untuk sampel yang mendapat perlakuan strategi pengorganisasian buku teks dengan masingmasing kelas terdiri atas 40 mahasiswa.

Langkah selanjutnya melakukan tes gaya kognitif, untuk mengidentifikasi mahasiswa yang mempunyai gaya kognitif spasial rendah dan spasial tinggi pada keempat kelas tersebut. Menentukan unit analisis penelitian dengan mengukur gaya kognitif mahasiswa di keempat kelas tersebut. Tes gaya kognitif dilaksanakan sebelum perkuliahan Gambar Mesin dimulai. Mahasiswa dengan skor gaya kognitif tinggi dan rendah ditentukan secara normatif pada subyek penelitian yang diukur berdasarkan nilai persentil P 27 ke bawah dan P 74 ke atas. Mahasiswa yang termasuk dalam nilai persentil P27 ke bawah digolongkan sebagai mahasiswa yang mempunyai gaya kognitif spasial tinggi sedangkan mahasiswa yang termasuk dalam nilai persentil P74 digolongkan sebagai mahasiswa yang mempunyai gaya kognitif spasial rendah.

\section{HASIL DAN PEMBAHASAN}

Secara umum, gabungan deskripsi data hasil penelitian dapat dilihat pada Tabel 3 di bawah ini. 
Tabel 3 Deskripsi Data Hasil Penelitian

\begin{tabular}{|c|c|c|c|c|}
\hline \multicolumn{2}{|c|}{$\begin{array}{r}\text { Strategi } \\
\text { Pembelajaran }\end{array}$} & $\begin{array}{l}\text { Elabo- } \\
\text { rasi }\end{array}$ & $\begin{array}{c}\text { Buku } \\
\text { teks }\end{array}$ & $\sum_{\text {baris }}$ \\
\hline \multirow{4}{*}{ Tinggi } & $\mathrm{n}$ & 16,00 & 16,00 & 32,00 \\
\hline & $\bar{X}$ & 72,63 & 60,44 & 66,54 \\
\hline & $\mathrm{S}$ & 9,29 & 9,93 & 9,61 \\
\hline & $s^{2}$ & 86,25 & 98,66 & 92,46 \\
\hline \multirow{5}{*}{ Rendah } & $\mathrm{n}$ & 16,00 & 16,00 & 32,00 \\
\hline & $X$ & 53.63 & 55.50 & 54,57 \\
\hline & $\mathrm{s}$ & 7.34 & 6.96 & 7,15 \\
\hline & $s^{2}$ & 53,85 & 48,40 & 51,13 \\
\hline & $\underline{\mathrm{n}}$ & 32,00 & 32,00 & 64,00 \\
\hline \multirow{3}{*}{$\sum$ kolom } & $\bar{X}$ & 63,13 & 57.97 & 60,55 \\
\hline & $\mathrm{S}$ & 12,69 & 8.80 & 10,75 \\
\hline & $\mathrm{s}^{2}$ & 160,95 & 77,45 & 119,2 \\
\hline
\end{tabular}

Hasil analisis data untuk mengukur keterampilan gambar mesin mahasiswa berkemampuan spasial tinggi yang diajar dengan strategi pembelajaran elaborasi menunjukkan rerata nilai 72,63. Mahasiswa berkemampuan spasial tinggi yang diajar dengan strategi pembelajaran buku teks menunjukkan rerata nilai 60,44 . Mahasiswa berkemampuan spasial rendah yang diajar dengan strategi pembelajaran elaborasi menunjukkan rerata nilai 53,63. Keterampilan gambar mesin mahasiswa berkemampuan spasial rendah yang diajar dengan strategi pembelajaran buku teks menunjukkan rerata nilai 55,50.

Hasil penelitian tentang adanya perbedaan pengaruh strategi pembelajaran elaborasi dan buku teks terhadap keterampilan gambar mesin mahasiswa ternyata diterima, artinya kedua strategi pembelajaran yang digunakan dalam penelitian ini akan mempengaruhi keterampilan mahasiswanya. Dari nilai rerata keterampilan gambar mesin juga dapat dilihat perbedaan antara mahasiswa yang diajar dengan strategi Elaborasi dan mahasiswa yang diajar dengan strategi buku teks. Tinjauan kondisi mahasiswa menunjukkan bahwa kondisi mahasiswa dari dua kelompok yang diteliti adalah sama, mereka telah menyelesaikan semester keempat di jurusan mesin dan tidak membedakan pria atau wanita. Bila dilihat dari faktor keberanian merangkai diagram gambar mesin, maka bagi mahasiswa yang belajar dengan Elaborasi lebih berani, mereka lebih banyak belajar dari kesalahan dan menanggulanginya sendiri tanpa rasa cemas atau takut celaka, baik merusak benda kerja maupun mesin itu sendiri. Kondisi ini menyatakan bahwa kegiatan dengan strategi elaborasi dilaksanakan tanpa mengalami rasa takut dan salah tindakan. Mahasiswa yang diajar dengan strategi buku teks kenyataannya harus lebih berhati-hati, lebih banyak mengalami rasa cemas berbuat kesalahan, karena kesalahan berarti kecelakaan bagi dirinya sendiri maupun alat gambar mesinnya. Kecemasan selama proses pembelajaran mengakibatkan kelambatan beradaptasi dengan alat itu sendiri, sehingga sangat mempengaruhi perkembangan pemahaman keterampilannya. Selain itu, mereka sangat sedikit menerima pengalaman mengerjakan rangkaian lain akibat keterbatasan waktu. Sebagian besar waktunya digunakan untuk mengikuti prosedur atau memahami imitasi dari pengajarnya.

Mahasiswa yang berkemampuan spasial tinggi mempunyai kecenderungan mudah beradaptasi dengan peralatan baru, mereka lebih senang belajar berhadapan langsung dengan peralatan. Interaksi langsung tersebut akan memudahkan dan mempercepat respon atas apa yang sedang mereka kerjakan. Hasil penelitian menunjukkan mereka yang berkemampuan spasial tinggi dan diajar dengan strategi pembelajarn Elaborasi ternyata penguasaan keterampilannnya lebih tinggi dibanding yang menggunakan strategi pembelajaran buku teks. Kondisi ini sesuai dengan pendapat Johnaseen bahwa mereka yang berkemampuan Spasial tinggi lebih senang memperoleh informasi berdasarkan umpan balik dan mengasimilasikan pada pengalaman sebelumnya. Kecepatan respon adalah sesuatu yang sulit diperoleh bila menggunakan strategi buku teks, karena strategi buku teksmengharuskan menyelesaikan satu kesatuan urutan kerja sesuai dengan prosedur yang telah ditetapkan. Selain kecepatan respon, 
jumlah latihan menyelesaikan masalah akan lebih banyak bagi mereka yang menggunakan strategi pembelajaran Elaborasi. Semakin banyak masalah yang diselesaikan akan menambah pengalaman sebagai bekal untuk menyelesaikan masalah berikutnya. Belajar dengan Elaborasi berarti melatih mental untuk menerima konsep-konsep baru yang terbentuk bersamaan dengan usaha pemecahan masalah. Keberanian mahasiswa berkemampuan Spasial tinggi untuk mencoba pemecahan masalah dengan berbagai cara sesuai dengan aturan sistem rangkaian diagram gambar mesin merupakan langkah yang sulit dilaksanakan bila mereka belajar dengan strategi buku teks.

Seseorang yang berkemampuan spasial rendah pada bidangnya mempengaruhi kemampuannya dalam hal menyelesaikan suatu masalah sesuai lingkup bidang bakatnya, terutama dalam hal kecepatan. John Carrol berpendapat bahwa seseorang yang memiliki kemampuan spasial rendah akan lebih lama menghabiskan waktu dalam mempelajari sesuatu daripada mereka yang berkemampuan spasial tinggi. Mereka kurang memperhatikan faktor kecepatan meskipun pada akhirnya dapat mnyelesaikannya. Keteraturan penyelesaian berjenjang sesuai dengan aturan yang harus diikuti akan lebih disukai daripada harus mencoba cara lain untuk menyelesaikannya.

Bila dilihat hasil pengujian hipotesisnya, meskipun menunjukkan tidak ada perbedaan keterampilan gambar mesin mahasiswa berkemampuan spasial rendah secara signifikan antara mereka yang diajar dengan strategi Elaborasi dan mahasiswa yang diajar dengan strategi buku teks, akan tetapi hasil rerata keterampilannya menunjukkan perbedaan. Perbedaan tersebut mununjukkan bahwa mahasiswa berkemampuan Spasial rendah tetap dapat berprestasi apabila menggunakan strategi pembelajaran yang tepat atau sesuai dengan kemampuan spasialnya.

Hasil penelitian ini menunjukkan interaksi antara strategi pembelajaran dan kemampuan spasial yang mempengaruhi keterampilan gambar mesin mahasiswa.
Strategi pembelajaran elaborasi memberikan hasil keterampilan gambar mesin yang lebih tinggi dari pada strategi pembelajaran buku teksbagi mahasiswa yang berkemampuan spasial tinggi. Bagi mahasiswa yang berkemampuan spasial tinggi, dalam penelitian ini, penggunaan pendekatan elaborasi pada pengajaran gambar mesin sebagai sarana memberi pemenuhan pengalaman yang cukup cepat. Kondisi ini sulit diperoleh pada pembelajaran dengan strategi buku teks, karena selama pembelajaran dalam penelitian ini mereka lebih sedikit memperoleh pengalaman mengerjakan pembuatan gambar mesin Keterbatasan mengerjakan gambar mesin tersebut akibat imitasi prosedur dan sikap kehati-hatian agar tidak ada salah. Sebaliknya bagi mahasiswa berkemampuan spasial rendah, mereka memerlukan bimbingan selama proses pembelajaran, selain itu contoh atau prosedur yang telah disampaikan oleh dosen merupakan panduan yang sangat menolong pada saat mhasiswa bekerja sendiri menggunakan berbagai peralatan gambar mesin. Kondisi pembelajaran dengan strategi buku teksini sesuai dengan pendapat Heinich dkk serta Joyce \& Well bahwa selama pembelajaran mereka harus mengamati setiap prosedur yang disampaikan, dan dapat mengimitasikan atau menirukan prosedur tersebut dalam pengawasan pengajar ahli.

Hasil penelitian ini menunjukkan bahwa mahasiswa berkemampuan spasial rendah yang diajar dengan strategi pembelajaran buku teks memberikan hasil keterampilan gambar mesin yang sedikit lebih tinggi dari pada mahasiswa yang diajar dengan strategi pembelajaran elaborasi. Untuk lebih jelasnya dapat dilihat Gambar 1 di bawah ini. 


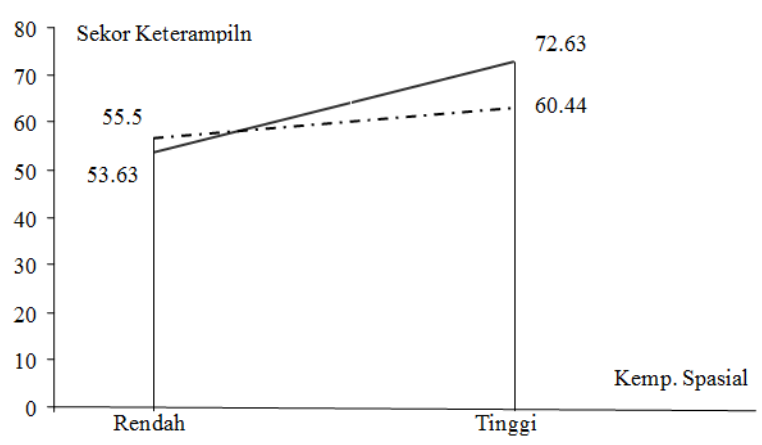

Keterangan :

$\overline{-\cdot-\cdot \cdot-\cdot-=}=$ Strategi Elaborasi

Gambar 1. Interaksi Strategi Pembelajaran Elaborasi dan Buku teks

Gambar 1 tersebut menunjukkan bahwa skor keterampilan gambar mesin mahasiswa yang berkemampuan spasial tinggi ternyata jauh berbeda perolehannya antara mahasiswa yang diajar dengan strategi pembelajaran Elaborasi dan buku teks, akan tetapi pada mahasiswa berkemampuan spasial rendah skor perolehannya tidak berbeda jauh. Meskipun tidak berbeda jauh, hasil rerata tersebut masih menunjukkan bahwa bagi mahasiswa berkemampuan spasial rendah akan lebih berhasil apabila menggunakan strategi pembelajaran buku teks.

Hasil interaksi yang terjadi dapat memperlihatkan bahwa pemilihan strategi pembelajaran khususnya dalam pembelajaran gambar mesin memerlukan informasi tentang kemampuan spasial yang telah dipunyai oleh mahasiswa, agar mahasiswa berkemampuan spasial rendah maupun tinggi tetap memperoleh kesempatan meningkatkan keterampilannya.

\section{SIMPULAN}

Data hasil penelitian dan pembahasan tersebut menunjukkan bahwa: (1) keterampilan gambar mesin mahasiswa yang diajar dengan strategi pembelajaran elaborasi lebih tinggi dari pada mahasiswa yang diajar dengan strategi pembelajaran buku teks, sehingga sebaiknya pembelajaran Gambar Mesin menggunakan strategi pembelajaran Elaborasi, (2) mahasiswa kelompok spasial tinggi yang diajar dengan strategi pembelajaran elaborasi, hasil keterampilan gambar mesin lebih tinggi dibandingkan dengan mahasiswa yang diajar dengan strategi pembelajaran buku teks, sehingga hasil pembelajaran keterampilan gambar mesin akan lebih baik bila menggunakan strategi pembelajaran elaborasi, (3) kelompok mahasiswa spasial rendah dan diajar dengan strategi pembelajaran elaborasi, keterampilan gambar mesin lebih rendah dibanding mahasiswa yang diajar dengan strategi pembelajaran buku teks, sehingga sebaiknya pembelajaran menggunakan strategi pembelajaran buku teks, (4) ketrampilan gambar mesin mahasiswa yang berlawanan, mengidentifikasikan adanya interaksi antara strategi pembelajaran dan spasial terhadap hasil keterampilan gambar mesin, memperlihatkan bahwa untuk memperoleh keterampilan gambar mesin bagi mahasiswa memiliki tingkatan spasial tinggi proses pembelajarannya dapat menggunakan kedua strategi tersebut dengan penekanan pada strategi pembelajaran elaborasi, sedangkan mahasiswa tingkat spasial rendah lebih efektif menggunakan strategi pembelajaran buku teks.

\section{DAFTAR RUJUKAN}

Giesecke, 1974, Technical Drawing, Machmillan Publishing CO, Inc: New York.

Gupta,V., dan Murty, PN, tanpa tahun, An Introduction to Engineering Design Method, New Delhi: tata Mc Graw Hill Publishing Company Limited.

Once Kurniawan, "Menata Ulang Proses Pembelajaran di Perguruan Tinggi," Peningkatan Kualitas dan Produktivitas SDM dengan Penerapan Teknologi Pembelajaran". makalah disampaikan pada Seminar Nasional Teknologi Pembelajaran, Jakarta,18-19 Juli 2002. 
Park, (1996) Adaptive Instructional System. Simon \& Schustrer Macmillan: New York.

Plomp, Tjeerd and Ely, Donald P.1996. International Encyclopedia of Educational Technology New York: Pergamon.

Reigeluth, C.M. (ed.). (1999). The Elaboration Theory Guidance for Scope and Sequence Decisions Instructional design theories and models: a New Paradigm of Instructional Theory. Lawrence Erlbauw Associates, Publishers. New Jersey
Task Force Systems Curriculum ACM, 2004 http://www.acm.org/mmresearch/acm.ht $\underline{m l}$

Witkin, H.A..,et.al (1977). “A Field-Dependent and Field Independent Cognitive Styles and Their Education Implication," Review of Educational Research. Vol47, May-1977.pp 43-51. 